\title{
The Methodology of Developing the System of Indicators to Evaluate the Socio-Economic Development Efficiency
}

\author{
Svetlana K. Demchenko* and Tatiana A. Melnikova \\ Siberian Federal University \\ 79 Svobodny, Krasnoyarsk, 660041, Russia
}

Received 09.08.2015, received in revised form 29.09.2015, accepted 03.10.2015

Globalization has an impact on the socio-economic development of any country. One of the major problems of the interdependent world community is not the cooperation of various socio-economic systems, but the interaction of the multilevel economic structures characterized both by the extent of development and the degree of involvement into the world differentiation of labour and the world economy. As $V$. Bandurin precisely notes, "state borders gradually lose their value, become more transparent and provide more opportunities for the freedom of movement of all types of resources".

Keywords: social production, socio-economic development, integration processes, transformation.

DOI: 10.17516/1997-1370-2015-8-11-2356-2384.

Research area: economics.

Prior to considering the system of indicators, which to this or that extent determine the socioeconomic development of the country, let us turn to the European experience of the socio-economic development.

F. Wishlade (Biiakov, 2004) considers the following criteria of the socio-economic development: in France these are geographic criteria (mountain and field haloes), as well as the urbanization degree; in Germany they consider the supply of the infrastructure; in Sweden these criteria include the climate, the distance from the world market, the size of the local labour market and the density of population; in Great Britain they take into consideration the periphery and the density of the population.
J. Galbraith notes that the challenges of the socio-economic development of the country are due to the fact that "the greatest single danger right now is in Russia, a catastrophic example of the failure of free market doctrine. Privatization and deregulation in Russia did not create efficient and competitive markets, but instead large and pernicious private monopolists, the oligarchs and the mafiosi" (Ekonomicheskaia..., 1976).

Given the fact that the socio-economic development is a multi-faceted concept, the indicators that reflect this development should be studied using a systematic approach. N. Fedorenko understands under the systematic approach to the study of economic phenomena, "a comprehensive study of the economy as

(C) Siberian Federal University. All rights reserved

* Corresponding author E-mail address: demchenko.svet@mail.ru 
a whole from the standpoint of the system analysis"1. L. Lopatnikov who believes that the systematic approach to the study of objects consisting of interconnected elements, clarifies the given concept as follows, “... it means taking into account these relationships, the study of certain economic units as the structural parts of more complex systems" (Fedorenko, 1975). The most complete definition of the concept of the system is given by V. Tiukhtin. He understands the system as "a set of interrelated components of a different nature that are ordered by relationships and have well-defined properties: this set is characterized by unity, which is expressed in the integrated features and functions of the set" ${ }^{2}$. "The concept of the socio-economic system as an artificial object is defined by B. Tsygichko, "the socioeconomic system refers to the class of artificial, organizational systems, i.e. organizations established and managed by people, where people make up the main determining component" (Galbraith).

I. Syroezhin draws attention to the properties common only for economic systems. In particular, such peculiar features include: a wide variety of resources consumed by the system and manufactured products (services), which tend to continuously increase; purposeful nature of the system as a whole and its separate units; complicated distinction between the managing and managed systems; impossibility of an automatic transfer of the evaluation criteria of the system to evaluate its structural elements; necessity to take into account economic interests and economic involvement, etc. (Illarionov, 1996).

The main feature of the economic system is a purposeful behaviour of any of its elements, when the connection of elements in the system is complemented by their indivisibility and intercorrelativity.
The variety of forms and methods to study the socio-economic development highlights that it is impossible to reflect this development by one or several indicators. If you try to take one indicator as a criterion, even quite aptly characterizing the success of the socio-economic development, for example, only GDP or the profits of the country's companies, the problems do not go away.

Therefore, neither a value indicator, no a physical indicator of the economic performance cannot claim to be a comprehensive evaluation criterion. Nevertheless, some economists believe that "it is the pace of the economic growth, the rate at which the GDP increases that reflects the level of efficiency of the national economy" (Lopatnikov, 1996).

The present study proposes to apply the method of studying the dynamics of the socioeconomic development. Early in 1939, the British economist Roy Harrod stated the fundamental equation of the economic growth that can explain a different state of dynamic equilibrium. The basic idea of his theory is called "the accelerator principle", i.e. the increase or decrease in the income cause the change in the investment proportionally to the changes in the income.

Analyzing the factors of the economic growth, Roy Harrod paid special attention to the engagement of the manpower. Moreover, he included the endogenous function of investments into his model, based on the acceleration principle and expectation of the entrepreneurs regarding the aggregate demand. The starting point of the model is investment, which has the purpose of the capacity expansion. In 1956, Robert Solow proposed a model that gave rise to the emergence of numerous studies based on macroeconomic production functions. R. Solow relates the economic growth with the change in the savings rate, population growth and technological progress. In his calculations he uses several indicators that reflect the situation: 
the scope of production, capital, labour and level of knowledge in the society. This model is more practical, while it allows not only to watch as the economy has changed over time, but to compare the growth of individual countries. R. Solow in his theory emphasized that one of the important conditions for the growth is the resource base, i.e. savings. The higher the level of savings, the higher the level of investment in production and resources for crisis situations. There is more capital, and therefore there are more resources for investment and, ultimately, the growth rates are higher. Robert Solow's growth model is designed to investigate the dependence of the economic growth on savings and capital accumulation.

To develop a system of indicators for the evaluation of the socio-economic development efficiency, the main processes of the country development and indicators, most succinctly characterizing these processes were taken as the basis of the conceptual and theoretical positions. In order to develop the system of indicators for the evaluation of the socio-economic development efficiency, let us define the dynamic criteria, while the system is based on the economic, mathematical and statistical methods of time series analysis.

The model of development of the dynamic criterion is based on the systematic approach that allows to reflect the most important socioeconomic development aspects of the country. This model proposes a generalized assessment of the actual dynamics of the socio-economic indicators by comparing it with the dynamics of their growth rates approved as a dynamic standard. The issues of building the dynamic standard have been already addressed in the works of a number of Russian scholars, but they were considered only at the regional level, or for a specific company. Such scholars are Biiakov, Syroezhin I.M., Pogostinskaia N.N., Pogostinskii
Iu.A., Saareper M.I., Eissner Iu.N., Stojanovic Dragisa, A.S. Tonkikh, A.Iu. Dianov.

The evaluation of the socio-economic development efficiency that we propose can be applied more widely and not be limited to a specific set of indicators. The approach to the study using the dynamic standard was proposed by I.M. Syroezhin (Syroezhin, 1980) and further developed by his followers N.N. Pogostinskaia, Iu.A. Pogostinskii (Pogostinskaia et al., 2000), et al. The theory of the dynamic standard is based on principles of dynamic comparability and subordination of socio-economic development indicators, that is characteristics and indicators incomparable in the static position become comparable in dynamics. The fact is that given the heterogeneity of indicators, it is difficult to make a comparison, when considering these indicators as static variables. The dynamics reflects a certain order, which is able to act as a standard for ranking the indicators by growth rates. Moreover, rate characteristics of the system in dynamics have some natural order and may be ranked and subordinated to each other. According to the idea of I.M. Syroezhin the activity of any system is the selection and implementation of a set of multiple possible connections, and maintaining or breaking the existing connections.

In turn, the system can be represented by a certain set of economic indicators. Using the ranking of indicators by growth rates, it is possible to create an order that can express the requirements for the best operation and can serve as a standard. This procedure is known as the regulatory system of indicators, i.e. a set of indicators structured by growth rates so that the maintenance of such order for the long time period provides the best operation of the economic system.

Using the dynamic model, it is possible to find out the dynamics of the socio-economic 


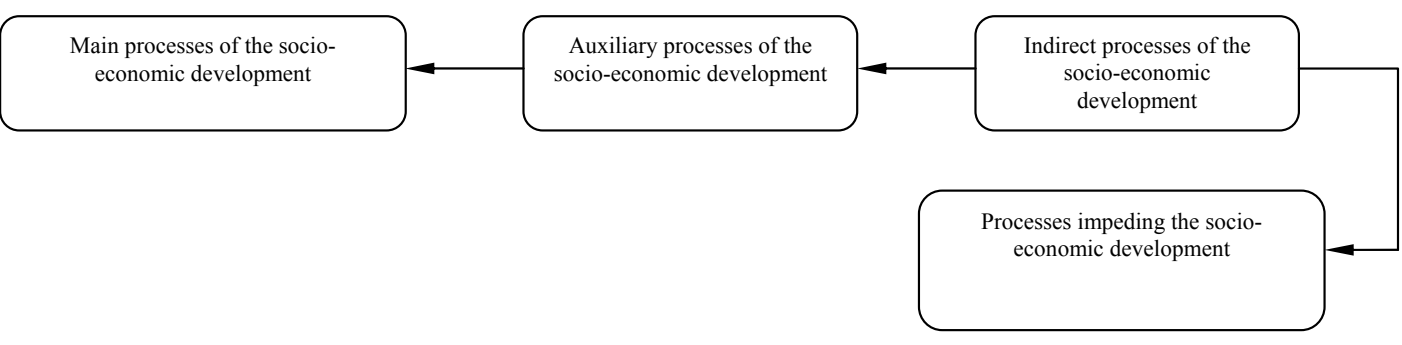

Fig. 1. The system of indictors of the socio-economic development processes

development efficiency, in contrast to the statistical characteristics that record such a development only at the certain point.

The socio-economic development is constantly changing, the final results change at each new step of this development. Taking into account the dynamics allows to distinguish one scenario of development from another, one specific move from the subsequent or previous one.

We propose a process methodological approach, which lies in considering the socioeconomic phenomena as processes that interact with each other.

The socio-economic development is the result of a parallel coordination of economic and social interests of many economic entities that are associated with a variety of subjects.

This overall process is presented as a set of particular processes realized by socio-economic entities through their business activities.

The efficiency of the socio-economic development depends on the systematized functioning of all particular processes.

Evaluation of the efficiency of the socioeconomic development should take into account the priority areas of both economic and social development. For example, the Russian Federation sets its strategic goals as follows, “... to achieve the level of the economic and social development corresponding to the status of Russia as a leading world power of the $21^{\text {st }}$ century that takes the leading positions in the global economic competition and ensures national security and implementation of the constitutional rights of its citizens".

We propose to classify particular processes forming the overall socio-economic development by the following systems:

1. The system of the main processes forming the kernel of the socio-economic development.

2. The system of the auxiliary processes supporting the system of the main processes.

3. The system of the processes indirectly connected with the socio-economic development that fulfills the functions of social security.

4. The system of the processes impeding the socio-economic development.

The systematic approach to the analysis of the socio-economic development is a tool that allows to solve various management problems successfully, whereas understanding all processes of the economic entity as an integrated system allows to evaluate the effectiveness of this development from the methodological perspective. The systematic approach involves the use of a number of general methodological provisions for the study of systems. First of all, let us determine the criteria for evaluating the efficiency of the socio-economic development.

Thus, as it has been previously determined, the socio-economic development can be investigated with the help of two types of criteria: 
static and dynamic. The static criterion is applied everywhere during the formation of statistical indicators for the socio-economic development, but the static criterion is not quite informative. The dynamic criterion reflects the development of the system of processes. It displays the state that the system of processes pursues.

The model of the socio-economic development efficiency can be written in the following generalized form: $\mathrm{A}>\mathrm{B}>\mathrm{C}>\mathrm{D}$, where A stands for the rate of development of the main socio-economic development processes; B is the rate of the development of the auxiliary processes of the socio-economic development; $\mathrm{C}$ is the rate of development of the indirect processes of the socio-economic development and $\mathrm{D}$ is the rate of development of the processes impeding the socioeconomic development.

Each process has several indicators directly characterizing each of the processes of the socioeconomic development. A set of indicators of the socio-economic development efficiency contains only those indicators that reflect the main socio-economic processes. The object of study is chosen depending on the purposes of the study and does not have any restrictions. Within the scope of the study it is proposed to arrange the indicators of the socio-economic development efficiency in such a way that each of the processes will be given a certain place in a certain system, i.e. indicators will have special connections with each other. Thus, the system of indicators will be arranged according to certain socio-economic processes.

The main requirement of the method is that indicators should fully reflect the socio-economic development process: the main processes of the socio-economic development; the auxiliary processes of the socio-economic development; the indirect processes of the socio-economic development; the processes impeding the socioeconomic development.
The structure of the system of indicators of the socio-economic development processes includes: the system of indicators characterizing the main processes of the socio-economic development; the system of indicators characterizing the auxiliary processes of the socio-economic development; the system of indicators characterizing the indirect processes of the socio-economic development; the system of indicators characterizing the processes impeding the socio-economic development. Let us consider each of the systems in more detail.

1. The system of indicators that reflects the main processes of the socio-economic development of the country. When evaluating the efficiency of the socio-economic development it is frequently difficult to choose one unified indicator of efficiency and, moreover, it is impossible to determine the purpose of an indicator through the quantitative parameters and characteristics. The main processes of the socio-economic development are characterized by the basic macroeconomic indicators. GDP is the major indicator of the socio-economic development. GDP measures the total national production in terms of money, i.e. in the value form. Money serves as a universal equivalent of the value of all goods, a unified measurer, which measures the value of all kinds of goods and services.

All products produced by the economy are divided into final and intermediate. GDP includes only the cost of the final product, in order to avoid repeated (double) counting. The cost of the final product therefore is counted with value added. Anything that is not a product or a service, are not included in GDP. The value of GDP does not include the payments that are not made in exchange for goods and services. Such payments include transfer payments and non-productive (financial) transactions.

The notion of "products made in the country with the help of both national and international 
factors of production" is important to understand the difference between GDP and GNP. GDP is the total market value of all final goods and services produced in the country involving both national and international factors of production; in this case it is only territorial factor that is important. In most developed countries, the difference between GNP and GDP does not exceed 1\%, the difference between them is significant for the countries receiving substantial income from tourism (Cyprus, Greece) or providing services, especially banking, to the citizens of other countries (Luxembourg, Switzerland). For example, let us consider the indicators of Russia's GDP over the last 10 years (Fig. 2).

The data of Fig. 2 allow us to conclude only on the tendency of increasing GDP over the last 10 years and that during the crisis of 2008-2009 there was a decrease of GDP. This indicator is not quite informative for the assessment of the effectiveness of the socio-economic development. It is therefore necessary to develop a system of indicators and to consider GDP and other parameters only in interrelation with one another. The efficiency of the socio-economic development also depends on the scope of foreign investments invested in the economy of the country. Increased foreign investment confirm the investment attractiveness of the country.

The scope of foreign investment reflects the investment attractiveness of the country, its growth shows the increasing confidence of foreign investors in the Russian economy. Foreign investment has had a serious impact on the national income of the society. Its dynamics determines the process of expanded reproduction. The investment incoming process and the growth of foreign investment affect the emergence of new enterprises that influence on the occurrence of new jobs, reduction of unemployment and raising the level of economically active population. The scope of foreign investment also affects GDP due to the additional production growth in Russia, the creation of new products or services.

The export is also an important component of the socio-economic development and is an indicator of the country's demand at the world market. In this regard, the role of Russia's international economic relations significantly increases as one of the most important factors of the socio-economic development, innovative upgrade and enhancement of the competitiveness of the economy, addressing key social issues. The value of the export in the development of

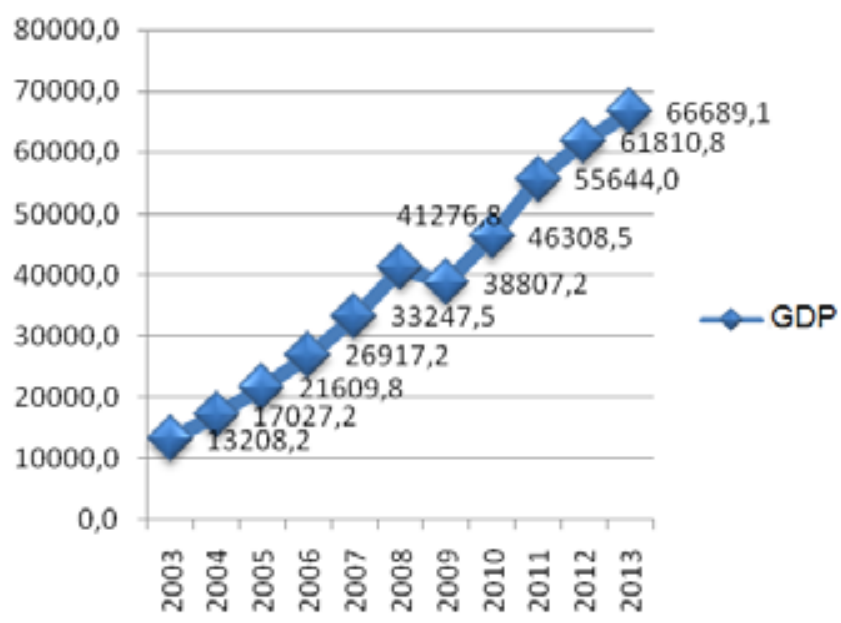

Fig. 2. GDP in Russia in 2003-2013, bln. RUB [12] 
the Russian economy cannot be overestimated. The export is connected with GDP and foreign investment. The higher GDP, the more goods are produced in Russia, which affects the scope of the export, which is also produced in Russia. The increase in the export affects the scope of foreign investment since investors are interested in supplying quality products to other countries.

Let us rank the system of indicators that characterize the main processes of the socioeconomic development of the country by the degree of correlation between them (Table 1).

2. The system of indicators reflecting the auxiliary processes of the socio-economic development of the country. The system of indicators characterizing the development of the auxiliary processes should include, in the first place, the population figures. The population size affects the growth of GDP and foreign investment and the number of economically active population, while the increase in the population results in the emergence of new manpower. The economically active population is the amount of people who have or may potentially have an independent source of earning for living. According to the
International Labour Organization, this category includes people aged from 10 to 72 years: employed (entrepreneurs and hired workers) and unemployed. The number of students reflects the level of education and the level of potential future employees. The number of university students is associated with the indicators of population and its economically active part. Today's students are the guaranteed future highly qualified manpower. Table 2 reflects these figures.

In our opinion, the population, its economically active part and the number of students getting their degrees are the key indicators of the socio-economic development of the country, as they are directly connected to GDP.

3. The system of indicators characterizing the indirect processes of the socio-economic development. The indirect processes are reflected by the minimum cost of living in the country, money expenditure and savings of the population, as well as housing availability. The indicators of the minimum cost of living should be put in first place, while with the increase of this indicator the living standards increase correspondingly.

Table 1. The system of indicators reflecting the main processes of the socio-economic development of the country

\begin{tabular}{|c|l|}
\hline The rank of the indicator in the system & \multicolumn{1}{|c|}{ The name of the indicator } \\
\hline 1 & GDP \\
\hline 2 & Inflow of foreign investment into the economy \\
\hline 3 & Export \\
\hline
\end{tabular}

Table 2. The system of indicators reflecting the auxiliary processes of the socio-economic development of the country.

\begin{tabular}{|c|l|}
\hline The rank of the indicator in the system & \multicolumn{1}{|c|}{ The name of the indicator } \\
\hline 1 & Population \\
\hline 2 & Economically active population \\
\hline 3 & The amount of university students at the beginning of the year \\
\hline
\end{tabular}


This indicator indirectly reflects the increase or decrease in the standard of living of the population. The social nature of the minimum cost of living is quite obvious. It is used to assess the level of life of the population and is an important reference point in establishing the minimum living wage and the minimum amount of the retirement pension. Thus, the minimum living wage cannot be below the minimum cost of living of working population (p. 1, Art. 133 of the Labour Code of the Russian Federation). The socio-economic development of the country depends on the availability of socio-economic benefits to the population. Therefore, the value of the minimum cost of living is considered to be the poverty line, i.e. the higher is the minimum cost of living, the better the socio-economic situation of the whole country is. We propose to put the indicator "Money expenditure and savings of the population" in the second place, as this indicator reflects the real picture of income and the level of its consumption and spending.

Theory and practice of savings have a long history, during which scientists and economists had been considering savings as the starting point playing an important role in the process of capital accumulation and sustainable economic development. As a result, today there is no doubt in the importance of the processes of the formation and use of savings, which depend not only on rational, but also irrational factors.

Despite the existing diversity of views on the motivations of people to save, most researchers agree that this process (the process of saving) can be managed by the state. Based on these assumptions, there are suggestions that state structures should establish specific funds of "national savings" in order to ensure the economic growth. The process of establishing such funds is often reduced to the implementation of a certain set of organizational and economic instruments by the state authorities: monetary, fiscal, etc., which are closely associated with the investment policy and allow to stimulate the improvement of the investment climate (Tiukhtin, 1972).

Housing availability to the population indirectly reflects the purchasing power of the population to buy some residential space. The increase in this indicator may indicate improving of the standard of living of the population, the emergence of the possibility either to buy new larger premises or individual premises.

The progressive development of the society is impossible without improving the level and quality of life. These are the most important indicators of the country's development. The standard of living should be considered as a degree of providing the family's necessary vital needs and the quality of life should be taken as the specific feature of such provision creating the basis for self-sufficiency and a new lifestyle. An important role in the socio-economic security belongs to the housing component. In turn, the improvement of living conditions significantly improves the quality of life, the purchase of premises or improvement of living conditions reinforces the sense of satisfaction and comfort.

Therefore, the system of these indicators is given in Table 3.

4. The system of indicators impeding the socio-economic development. The crime rate is an important indicator, which reflects the social processes in the country. The lower the crime rate, the better the socio-economic situation in the country. The main reasons for the emergence and growth of crime are social and economic problems of the country. The crime rate and its dynamics are related to the socio-economic development. The unemployment rate also reflects the state of the society, and this rate has a direct impact on the crime rate. With the high level of unemployment, the crime rate is always high.

The children death rate is one of the most important indicators that reflect the negative 
Table 3. The indicators reflecting indirect processes of the socio-economic development.

\begin{tabular}{|c|l|}
\hline The rank of the indicator in the system & \multicolumn{1}{|c|}{ The name of the indicator } \\
\hline 1 & Minimum cost of living \\
\hline 2 & Money expenditures and savings of the population \\
\hline 3 & Housing availability to the population \\
\hline
\end{tabular}

Table 4. The system of indicators that negatively affect the efficient socio-economic development.

\begin{tabular}{|c|l|}
\hline The rank of the indicator in the system & The name of the indicator \\
\hline 1 & Crime rate \\
\hline 2 & Unemployment rate \\
\hline 3 & Children death rate \\
\hline
\end{tabular}

Table 5. The system of indictors to evaluate the efficiency of the socio-economic development.

\begin{tabular}{|c|l|}
\hline The rank of the indicator in the system & \multicolumn{1}{|c|}{ The name of the indicator } \\
\hline 1 & GDP \\
\hline 2 & Inflow of foreign investment into the economy \\
\hline 3 & Export \\
\hline 4 & Population \\
\hline 5 & Economically active population \\
\hline 6 & The amount of university students at the beginning of the year \\
\hline 7 & Minimum cost of living \\
\hline 8 & Money expenditures and savings of the population \\
\hline 9 & Housing availability to the population \\
\hline 10 & Crime rate \\
\hline 11 & Unemployment rate \\
\hline 12 & Children death rate \\
\hline
\end{tabular}

impact on the socio-economic development of the country. With the high rate of children death, the population growth of the country slows down, and this has a direct impact on all the indicators of the socio-economic sphere. The resulting system of indicators characterizes the processes that have a negative impact on the effective socioeconomic development (Table 4). Performance indicators of the socio-economic development that have been formed by four types of processes allow to develop a complete system of indicators reflecting the effective reference socio-economic development of the country (Table 5).

It should be noted that the system of indicators included into each process can vary depending on the purpose of research, the researcher's preferences and the specificity of the object being studied. We have proposed 12 indicators that are directly connected with each other and with the socio-economic development of the country. 
These indicators are ranked in a specific way: the greatest acceleration indicator should be GDP, the lowest acceleration indicator should be the children death rate. This is the reference of the ideal, in the authors' view, development of the socio-economic system.

The proposed model for evaluating the efficiency of the socio-economic development of the country is based on the following approach: at first, the structure of the effective socio-economic development is analyzed, then an integrating indicator is formed, which allows to compare the estimates. There is such a characteristic of the motion as acceleration. It has the same property in any kind of inertial reference systems, allowing to compare diverse indicators of the socio-economic development no matter what units of measurement are considered. In this study, acceleration gets special economic content. Acceleration is used to achieve comparability of indicators of the socioeconomic development.

The socio-economic development indicators and evaluation of its performance will be presented in the form of time series. The calculation of the growth rate of the indictor leads to the determination of its velocity and acceleration is fixed by means of calculation of the growth rate. With the acceleration values at each time point for all indicators, it is possible to determine the efficiency of the socio-economic system as a result of evaluation of the processes that occur in it. Defining the priorities of temporal changes in a dynamic criterion for each indicator and the system of indicators, we can to compare the criterial state of the system and the actual one. To do this, a rank correlation should be implemented.

For the analysis, only official statistic data can be used. The present research compares the systems of socio-economic development indicators for the years 1994-2003 and 20042013. It allows assessing the efficiency of socio- economic development for the last decade in comparison with the development of the country in the late $20^{\text {th }}$ century. The two decades' comparison provides an opportunity to follow the changes in the socio-economic development of the country, the synchrony and coordination of the main processes' development etc. There are several stages of modeling the socio-economic development efficiency assessment.

The first stage is formalization of the dynamic criterion actualized in the criterion dynamics order of the indicators selected for the socioeconomic processes' efficiency assessment. The criterion order is a series of ranks consisting of the selected indices, arranged under the accepted criterion: main socio-economic development processes, auxiliary socio-economic development processes, indirect socio-economic development processes and the processes impeding socioeconomic development.

The criterion order is not an absolute value; it is a system of the indicators selected in paragraph 3.1 , with the acceleration dynamics complying with their standard order (Fig. 3).

The second stage is the temporal series smoothing procedure. The primary treatment (smoothing) of the temporal series should be carried out with the normalization procedure. For example, in the temporal series $X_{1}, X_{2}, X_{K}$ every new smoothed series element $S_{i}$ is calculated according to Formula 1:

$\mathrm{S}_{\mathrm{i}}=1+\left(\mathrm{X}_{\mathrm{i}}-\mathrm{Me}\right) /$

$\left(X_{\max }-X_{\min }+1\right), i=1, \ldots, k$,

where $\mathrm{Me}$ is the temporal series median; $\mathrm{X}_{\max }$, $\mathrm{X}_{\min }$ are the maximal and the minimal members of the series.

The advantage of the present approach is the decrease of total transformation error. The research (Syroezhin, 1980) has shown that the error of median smoothing is around $4 \%$, for 


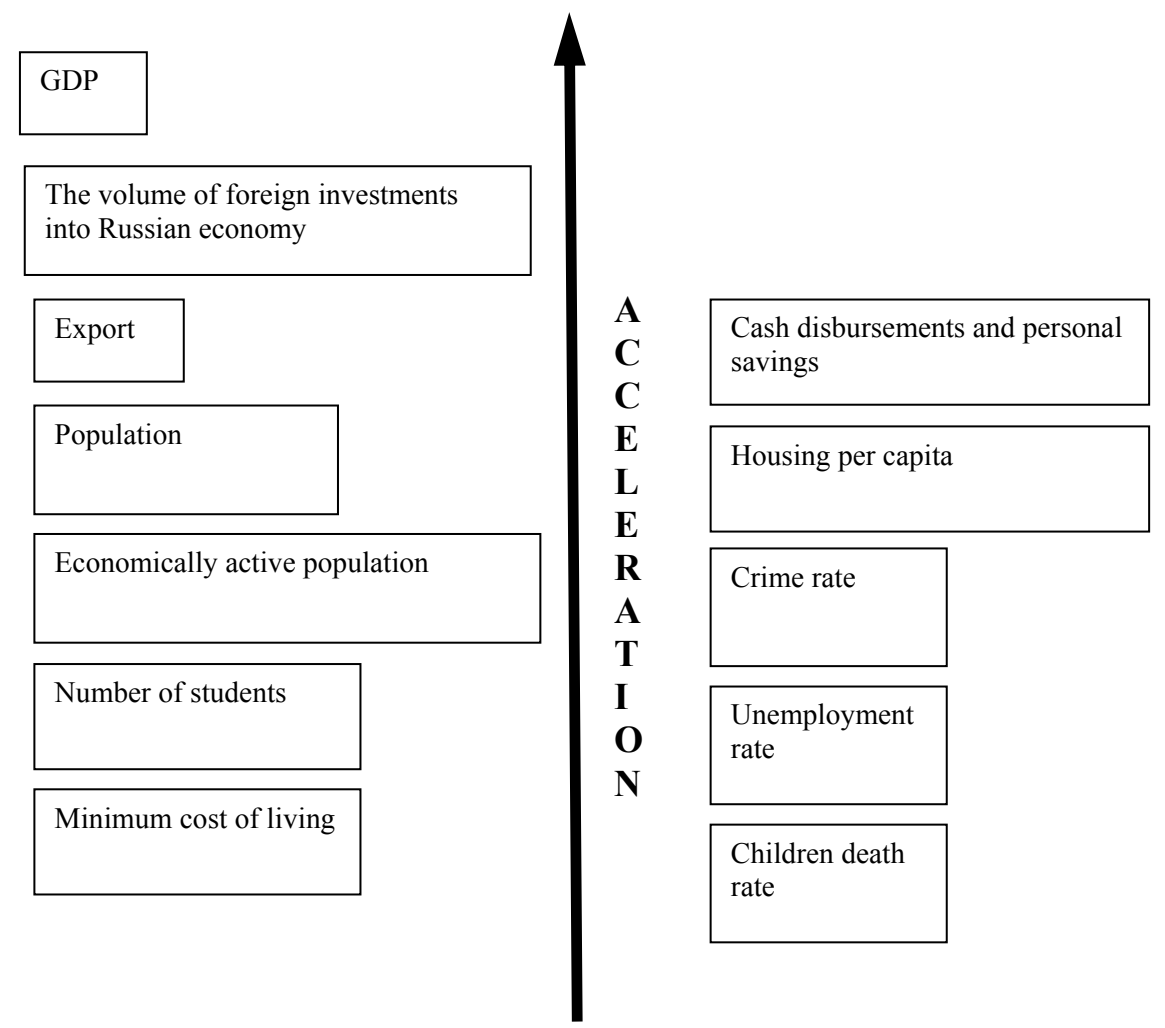

Fig. 3. Reference order of the indicators' acceleration (Tsygichko, 1991)

moving average smoothing this rate is $8 \%$, and for exponential smoothing it is $11 \%$. At the growth rate calculation, median smoothing provides easy calculation of all the indices, as the transformed temporal series has no zero or negative components at the absolute coincidence between the present trend and the initial one. At the third stage of the model development it is necessary to make up the actual rank series of the indicators' movement. It requires the following actions: to calculate the indicators' growth rate; calculate the acceleration of the indicator's value changes; rank the indicators in the descending order according to the acceleration of their movement. Therefore, rank one is given to the indicator with the greatest acceleration, and the last rank is given to the one with the lowest acceleration.

One of the problems that may arise at the index calculation is ranking the indices with the equal acceleration values. It has to be determined semantically, according to the objectives of each research. The result of the third stage calculations is several rank series (Table 6). They illustrate the dynamics and movement structure of the analyzed socio-economic development indicators.

The fourth stage of research includes comparison and collation of the two rank series: the criterion and actual series. In order to assess the proximity, concordance and discordance of actual and reference series we should use Spearman's rank correlation coefficient (based on deviations) and Kendall's rank correlation coefficient (based on inversions).

1. For every listed indicator the square difference (deviation) between its place (rank) in the normative sequence and the rank in the actual sequence is calculated according to Formula 2: 
Table 6. Indicators' movement rank matrix

\begin{tabular}{|c|c|c|c|c|c|c|}
\hline \multirow{2}{*}{ Indicator } & \multirow{2}{*}{$\begin{array}{l}\text { Criterion } \\
\text { movement } \\
\text { order }\end{array}$} & \multicolumn{5}{|c|}{ Actual movement order for the period } \\
\hline & & $\mathrm{T}_{1}$ & $\mathrm{~T}_{2}$ & $\mathrm{~T}_{3}$ & $\ldots$ & $\mathrm{T}_{\mathrm{K}}$ \\
\hline Indictor 1 & 1 & $\mathrm{X}_{11}$ & $\mathrm{X}_{12}$ & $\mathrm{X}_{13}$ & $\ldots$ & $\mathrm{X}_{1 \mathrm{~K}}$ \\
\hline Indicator 2 & 2 & $\mathrm{X}_{21}$ & $\mathrm{X}_{22}$ & $\mathrm{X}_{23}$ & $\ldots$ & $\mathrm{X}_{2 \mathrm{~K}}$ \\
\hline Indicator 3 & 3 & $\mathrm{X}_{31}$ & $\mathrm{X}_{32}$ & $\mathrm{X}_{33}$ & ... & $\mathrm{X}_{3 \mathrm{~K}}$ \\
\hline$\ldots$ & $\ldots$ & $\ldots$ & $\ldots$ & $\ldots$ & $\ldots$ & $\ldots$ \\
\hline Indicator $\mathrm{N}$ & $\mathrm{N}$ & $\mathrm{X}_{\mathrm{N} 1}$ & $\mathrm{X}_{\mathrm{N} 2}$ & $\mathrm{X}_{\mathrm{N} 3}$ & $\ldots$ & $\mathrm{X}_{\mathrm{NK}}$ \\
\hline
\end{tabular}

$\mathrm{Y}_{\mathrm{i}}=\left(\mathrm{X}_{\mathrm{i}}-\mathrm{X}_{\mathrm{k}}\right)^{2}$

where $\mathrm{Y}_{\mathrm{i}}$ is the difference between the rank of the $\mathrm{i}$-th index in the criterion and the actual sequences; $\mathrm{X}_{\mathrm{k}}$ is the indictor's rank in the criterion sequence; $\mathrm{X}_{\mathrm{i}}$ is the indicator's rank in the actual sequence.

2. After, the sum of squared deviations for all the indicators within the current period of time is calculated and Spearman's coefficient is found, according to Formula (3):

$\mathrm{K}_{\text {откл }}=1-\frac{6 \cdot \sum_{\mathrm{i}=1}^{\mathrm{N}} \mathrm{Y}_{\mathrm{i}}}{\mathrm{N} \cdot\left(\mathrm{N}^{2}-1\right)}$.

Kendall's rank correlation coefficient is calculated in several steps. First of all, for every indictor it is necessary to calculate the number of other indicators with a greater rank in the criterion sequence than that of the given indicator, and a lower rank than that of the given indicator in the actual sequence:

$\mathrm{S}=\sum_{\mathrm{p}=\mathrm{k}+1}^{\mathrm{N}} \mathrm{a}_{\mathrm{p}}, \quad \mathrm{a}_{\mathrm{p}}=\left\{\begin{array}{l}1, \mathrm{x}_{\mathrm{k}} \succ \mathrm{x}_{\mathrm{i}} \\ 0, \mathrm{x}_{\mathrm{k}} \prec \mathrm{x}_{\mathrm{i}}\end{array}\right.$

where $\mathrm{k}$ is the rank of the given indicator in the criterion sequence; $\mathrm{S}$ is the number of inversions of the given indicator; $\mathrm{p}$ is the ranks of the indicators compared to the given indicator; $\mathrm{N}$ is the number of indicators included into the system features list; $a_{p}$ is the function illustrating whether the given indicator is inverse to the compared indicator (if yes, then $\mathrm{a}_{\mathrm{p}}=1$, and if no, $\mathrm{a}_{\mathrm{p}}=0$ ); $\mathrm{x}_{\mathrm{k}}\left(\mathrm{x}_{\mathrm{i}}\right)$ is actual sequence rank of the indicator having the $\operatorname{rank} \mathrm{k}(\mathrm{p})$ in the criterion sequence.

Secondly, the total number of inversions for all indicators is calculated and Kendall's correlation coefficient is determined:

$\mathrm{K}_{\text {инвер }}=1-\frac{4 \cdot \sum_{\mathrm{i}=1}^{\mathrm{N}} \mathrm{S}_{\mathrm{i}}}{\mathrm{N} \cdot(\mathrm{N}-1)}$

Both coefficients $\left(\mathrm{K}_{\text {откл }}, \mathrm{K}_{\text {инвер }}\right)$ assess the proximity of the given rank series to the series taken as a reference (criterion) within the range from -1 to +1 . The value +1 indicates the concordance of the actual and the criterion series, while -1 stands for their complete discordance.

The obtained results should be analyzed as follows. If the indicators are positive, it means improvement of the socio-economic development and its efficiency. If the indicators are negative, it means the inefficiency of the socio-economic development and a deviation of the development system from its perfect form, which also witnesses the decrease in the efficiency of the socio-economic development.

The indicator of the final assessment of proximity between the actual structure of the system indicators' movement and the criterion 
(reference) one, based on the two rank correlation coefficients valid for the given period of time, can be calculated according to the formula:

$$
\mathrm{R}=\frac{\left(1+\mathrm{K}_{\text {откл }}\right) \cdot\left(1+\mathrm{K}_{\text {инвер }}\right)}{4} \text {. }
$$

The final assessment demonstrates how much the character of changes in the system links' structure corresponds to the selected assessment criterion. In other words, we can say that this indicator is used for evaluating the efficiency of the strategic decisions under the given criterion. The indicator varies from 0 to $+1 .+1$ stands for the complete concordance of changes in the system links' structure with the given criterion, and 0 means complete discordance between the system changes and the selected criterion. The segment $\mathrm{P}^{\mathrm{K}}$ limited by the time interval $\left(t_{1}, t_{k}\right)$ reflects the situation when at any moment the potential of the country is fully employed. The segment limited by the polyline and the curve within the time interval $\left(t_{1}, t_{k}\right)$ reflects the actual assessment of the socioeconomic development efficiency.

The value of this level can be assessed as a proportion of the areas of the second and the first sectors. Assuming that $\mathrm{R}^{\mathrm{K}}=1$, the following simple formula is presented:
$\mathrm{L}=\frac{0,5 \cdot\left(\mathrm{R}_{1}+\mathrm{R}_{\mathrm{r}}\right)+\sum_{\mathrm{i}=2}^{\mathrm{r}-1} \mathrm{R}_{\mathrm{i}}}{\mathrm{T}-1}$,

where $\mathrm{T}$ is the number of time periods; $\mathrm{R}$ is the final assessment indicator calculated according to Formula 6. The better the socioeconomic development processes in the country are coordinated, the greater the $\mathrm{L}$ value is (maximum $\mathrm{L}=1$, minimum $\mathrm{L}=0$ ). Therefore, the quantitative efficiency assessment of socioeconomic development is formed. After this it is required to add qualitative assessment to make a conclusion on the strong and weak points of the socio-economic development.

The input data of such assessment is the acceleration of the indicator's movement for each system of socio-economic development efficiency assessment. To provide it, the authors use weighting factors to reveal the causes of acceleration for each indicator under study. The weight of each acceleration indicator determines its place in the system of a certain block of indicators and depends on the number such indicators within the block system. The factor values for systems of blocks including over ten indicators are shown in Table 6.

Having calculated the mean acceleration values for each of the four blocks, we make up

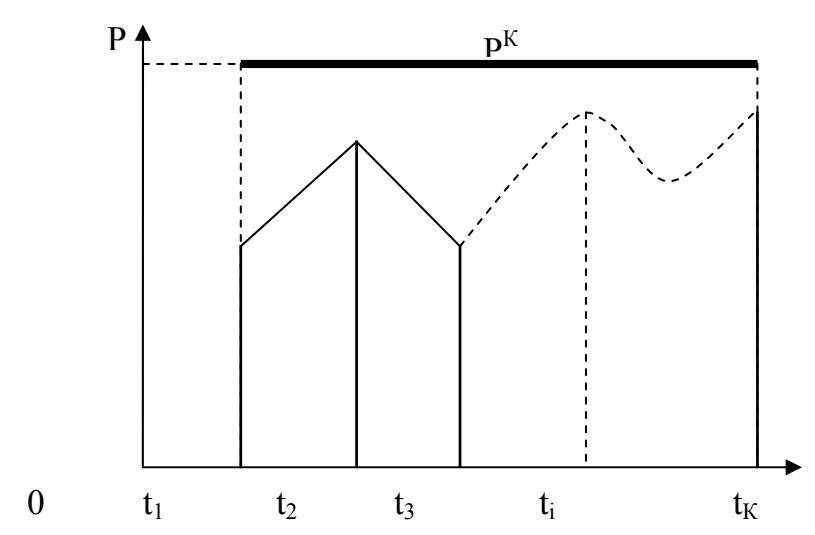

Fig. 4. Geometrical interpretation of the socio-economic development efficiency 
Table 7. Weighting factors for the calculation of the mean acceleration value of an indicator within a block.

\begin{tabular}{|c|c|c|c|c|c|c|c|c|c|c|}
\hline \multirow{2}{*}{$\begin{array}{c}\text { Indicator } \\
\text { No. }\end{array}$} & \multicolumn{9}{|c|}{ Number of indicators within one block } \\
\cline { 2 - 11 } & 2 & 3 & 4 & 5 & 6 & 7 & 8 & 9 & 10 \\
\hline 1 & 0.622 & 0.472 & 0.386 & 0.329 & 0.288 & 0.256 & 0.232 & 0.211 & 0.195 \\
\hline 2 & 0.378 & 0.286 & 0.234 & 0.199 & 0.174 & 0.155 & 0.140 & 0.128 & 0.118 \\
\hline 3 & - & 0.242 & 0.198 & 0.169 & 0.148 & 0.132 & 0.119 & 0.109 & 0.100 \\
\hline 4 & - & - & 0.182 & 0.155 & 0.136 & 0.121 & 0.109 & 0.100 & 0.092 \\
\hline 5 & - & - & - & 0.148 & 0.129 & 0.115 & 0.104 & 0.095 & 0.088 \\
\hline 6 & - & - & - & - & 0.125 & 0.111 & 0.101 & 0.092 & 0.085 \\
\hline 7 & - & - & - & - & - & 0.109 & 0.098 & 0.090 & 0.083 \\
\hline 8 & - & - & - & - & - & - & 0.097 & 0.088 & 0.081 \\
\hline 9 & - & - & - & - & - & - & - & 0.087 & 0.080 \\
\hline 10 & - & - & - & - & - & - & - & - & 0.079 \\
\hline
\end{tabular}

Table 8. Data matrix for the determination of weak and strong points

\begin{tabular}{|l|c|c|c|c|c|}
\hline \multirow{2}{*}{\multicolumn{2}{c|}{ Name of the system of indicators }} & \multicolumn{5}{c|}{ Mean value of the block for the selected period } \\
\cline { 2 - 6 } & $\mathrm{T}_{1}$ & $\mathrm{~T}_{2}$ & $\mathrm{~T}_{3}$ & $\ldots$ & $\mathrm{T}_{\mathrm{K}}$ \\
\hline Main socio-economic development processes & $\mathrm{U}_{11}$ & $\mathrm{U}_{12}$ & $\mathrm{U}_{13}$ & $\ldots$ & $\mathrm{U}_{1 \mathrm{~K}}$ \\
\hline Auxiliary socio-economic development processes & $\mathrm{U}_{21}$ & $\mathrm{U}_{22}$ & $\mathrm{U}_{23}$ & $\ldots$ & $\mathrm{U}_{2 \mathrm{~K}}$ \\
\hline Indirect socio-economic development processes & $\mathrm{U}_{31}$ & $\mathrm{U}_{32}$ & $\mathrm{U}_{33}$ & $\ldots$ & $\mathrm{U}_{3 \mathrm{~K}}$ \\
\hline The processes impeding socio-economic development & $\mathrm{U}_{41}$ & $\mathrm{U}_{42}$ & $\mathrm{U}_{43}$ & $\ldots$ & $\mathrm{U}_{4 \mathrm{~K}}$ \\
\hline
\end{tabular}

the matrix (Table 8) to point out the weak (the least efficient) and the strong (the most efficient) indicators of the socio-economic development. The changes of the values shown in Table 8 with provision for the criterion attribute show the process of transformation of the socio-economic development system and draw conclusions on the causes that gave rise to such transformation. For quantitative assessment of the transformation process, it is suggested to calculate the value of synchrony of socio-economic development.

The synchrony rate is defined in relation to the main socio-economic development indicators, as they are the ones that determine the tendency of a country's development. This indicator reflects the synchrony level of the other systems of indicators in relation to the system of the main indicators. The indicator varies from -1 to +1 , and the highest value is possible only in the case of absolute synchrony of the processes and the lowest one - at the absolute asynchrony of the processes' development.

$\mathrm{SY}=\left(\mathrm{K}_{1}+\mathrm{K}_{2}+\mathrm{K}_{3}\right) / 3$

where $K_{1}$ is the factor of correlation between the main and auxiliary processes' development rates; $\mathrm{K}_{2}$ is the factor of correlation between the main and indirect processes' development rates; $\mathrm{K}_{3}$ is the factor of correlation between the development rates of the main processes and the processes impeding socio-economic development.

Therefore, the synchrony and mathematic statistics provide an opportunity to obtain the most accurate data on the socio-economic 
development. The obtained research results serve as the basis for the following classification of the efficiency of the socio-economic indicators.

At all the studied phases of the socioeconomic development life cycle the main processes of a country act as a buffer smoothing the contradictions caused by such development. We refer to a variant of the socio-economic development as to a perfect one if the greatest acceleration value is that of the individual processes included into the main processes block, and the lowest acceleration value is that of the processes impeding socio-economic development. In other words, the aggregate socioeconomic development process shall be trended along the most optimal trajectory in respect with a certain criterion. Based on the present substantiated method for the socio-economic development efficiency assessment, one can imagine a perfect administration model where all the processes would be synchronized and wellcoordinated. It can only be achieved if the main processes reach the greatest acceleration rate, the auxiliary processes come second, the indirect processes have an average acceleration rate and the processes making a negative impact on the socio-economic development of the country show the lowest acceleration rate.

It can be graphically presented as follows (Fig. 5).

Therefore, the authors have developed some adjusted recommendations for the assessment of the socio-economic development efficiency including various development scenarios, such as formation, development, recession, depression, similar to the economic processes life cycles. The stages of the socioeconomic development depend on the process development rate described in the methodology for the assessment of such development efficiency. After the assessment of the socioeconomic development efficiency according to the suggested methodology it is required to strive for designing a perfect model of the socio-economic development system.

To study the efficiency of the socio-economic development of Russia let us take the input data from some open statistic sources ${ }^{3}$ (Appendix A). To simplify the calculation process, let us introduce the conventional notation for the designation of data (Table 10).

The indicatros shall be designated as follows: A1_1998 is the GDP indicator for the year 1998. The obtained relative indicatros are shown in the integrated table (Appendix B). Tables 11 and 12 show the calculated acceleration and rank the acceleration indicators according to the calculation method.

After obtaining the data on the actual movement of indicators it is necessary to use SPSS 17.0 statistic software to assess the data on the basis of Spearman's (deviation) and Kendall's (inversion) rank correlation coefficients ${ }^{4}$. Based on the obtained statistic correlation, let us make up the correlation table on the basis of Kendall's and Spearman's coefficients for each period of

Table 9. Functions of the socio-economic development elements by its life cycle stages

\begin{tabular}{|l|l|l|}
\hline \multicolumn{1}{|c|}{ Element/phase } & \multicolumn{1}{c|}{ Process } & \multicolumn{1}{c|}{ Process dynamics } \\
\hline Formation of the efficient socio-economic indicators & Integrating & Process synchronization \\
\hline Development of the efficient socio-economic indicators & Selecting & Process acceleration \\
\hline Recession of the efficient socio-economic indicators & Stabilizing & Process deceleration \\
\hline Depression of the efficient socio-economic indicators & Disintegrating & Process desynchronization \\
\hline
\end{tabular}




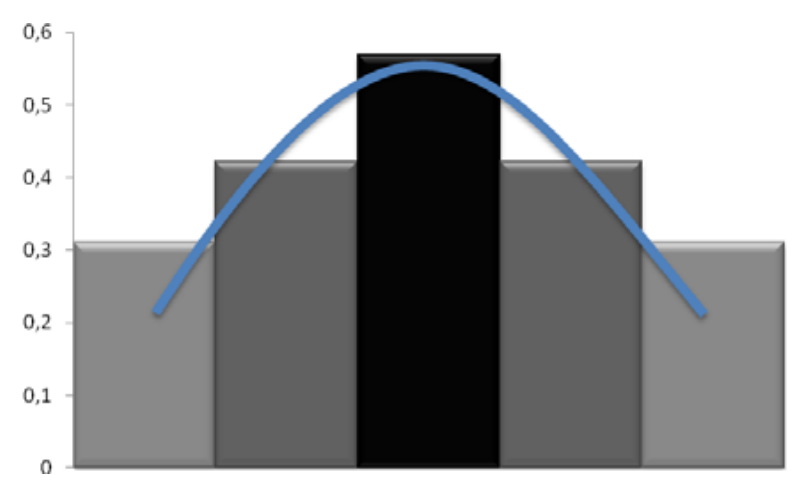

Fig. 5. Transformation of socio-economic development processes (perfect acceleration model), where $\mathbf{\square}-$ main socio-economic development processes; - auxiliary socio-economic development processes; $\square$ - indirect socio-economic development processes

Table 10. Conventional notation for the socio-economic development data

\begin{tabular}{|c|c|}
\hline Conventional notation of the indicators & Names of the indicators \\
\hline \multicolumn{2}{|c|}{ A - Main socio-economic development processes' indicators } \\
\hline A1 & GDP \\
\hline A 2 & The volume of foreign investments into Russian economy \\
\hline A3 & Export \\
\hline B - Auxiliary socio-economic development processes' indicators \\
\hline B1 & Population \\
\hline B2 & Number of students \\
\hline B3 & Cash disbursements and personal savings \\
\hline C1 - Indirect socio-economic processes' indicators \\
\hline C2 & Housing per capita \\
\hline C3 & Minimum cost of living \\
\hline D1 & C - Indicatros impeding socio-economic development \\
\hline D2 & Crime rate \\
\hline D3 & Children death rate \\
\hline
\end{tabular}

each year (Tables 12 and 13). From the information presented in Table 12 we can conclude that in the period lof the years 1997, 1998, 2003 and 2003 the indicators' correlation was negative, and in the other years it was straight, i.e. positive. The negative value of the socio-economic development correlation was noticed during the crisis of $1997-$ 1998.
The coefficients described above can be interpreted as follows. If the values of the coefficients lie in the positive part of the axis, it means a certain improvement in the structure of the socio-economic development system features and an increase of the efficiency of such development. If the values of coefficients are negative, it means that the selected system of the socio-economic 
Table 11. Ranking of the acceleration indicatros in the common time series for period 1 (1994-2003).

\begin{tabular}{|c|c|c|c|c|c|c|c|c|c|c|c|}
\hline \multirow{2}{*}{ No. } & \multicolumn{10}{|c|}{ Actual indicator's dynamics } & \multirow{2}{*}{ Reference } \\
\cline { 2 - 13 } & 1994 & 1995 & 1996 & 1997 & 1998 & 1999 & 2000 & 2001 & 2002 & 2003 & 1 \\
\hline A1 & 3 & 6 & 6 & 7 & 9 & 3 & 5 & 9 & 6 & 7 & 2 \\
\hline A2 & 5 & 3 & 2 & 5 & 12 & 12 & 2 & 3 & 4 & 4 & 3 \\
\hline A3 & 2 & 2 & 8 & 3 & 11 & 6 & 1 & 10 & 5 & 3 & 4 \\
\hline B1 & 9 & 4 & 9 & 8 & 7 & 10 & 8 & 5 & 11 & 11 & 5 \\
\hline B2 & 11 & 11 & 1 & 11 & 2 & 1 & 12 & 11 & 2 & 10 & 6 \\
\hline B3 & 6 & 9 & 4 & 4 & 6 & 8 & 4 & 12 & 1 & 12 & 7 \\
\hline C1 & 4 & 5 & 7 & 10 & 5 & 2 & 7 & 6 & 7 & 9 & 8 \\
\hline C2 & 7 & 8 & 3 & 9 & 10 & 5 & 6 & 4 & 9 & 6 & 9 \\
\hline C3 & 10 & 10 & 5 & 6 & 4 & 9 & 3 & 8 & 8 & 8 & 10 \\
\hline D1 & 12 & 1 & 12 & 12 & 1 & 4 & 11 & 2 & 12 & 1 & 11 \\
\hline D2 & 1 & 12 & 11 & 1 & 8 & 11 & 10 & 7 & 3 & 2 & 12 \\
\hline D3 & 8 & 7 & 10 & 2 & 3 & 7 & 9 & 1 & 10 & 5 & 4 \\
\hline
\end{tabular}

Table 12. Ranking of the acceleration indicators in the common time series for period 2 (2004-2013)

\begin{tabular}{|c|c|c|c|c|c|c|c|c|c|c|c|}
\hline \multirow{2}{*}{ No. } & \multicolumn{10}{|c|}{ Actual indicator's dynamics } & \multirow{2}{*}{ Reference } \\
\cline { 2 - 13 } & 2004 & 2005 & 2006 & 2007 & 2008 & 2009 & 2010 & 2011 & 2012 & 2013 & 1 \\
\hline A1 & 2 & 8 & 5 & 6 & 5 & 10 & 4 & 7 & 6 & 8 & 2 \\
\hline A2 & 3 & 7 & 10 & 1 & 12 & 8 & 2 & 3 & 11 & 2 & 3 \\
\hline A3 & 1 & 6 & 7 & 10 & 2 & 12 & 1 & 9 & 9 & 11 & 4 \\
\hline B1 & 8 & 9 & 6 & 5 & 3 & 4 & 3 & 12 & 3 & 4 & 5 \\
\hline B2 & 12 & 1 & 12 & 2 & 11 & 11 & 5 & 4 & 8 & 10 & 6 \\
\hline B3 & 5 & 11 & 4 & 9 & 7 & 6 & 9 & 1 & 12 & 5 & 7 \\
\hline C1 & 6 & 3 & 8 & 8 & 4 & 9 & 8 & 8 & 7 & 3 & 8 \\
\hline C2 & 7 & 4 & 3 & 7 & 8 & 7 & 6 & 11 & 5 & 6 & 9 \\
\hline C3 & 4 & 5 & 9 & 4 & 6 & 5 & 7 & 10 & 4 & 9 & 10 \\
\hline D1 & 10 & 2 & 11 & 12 & 10 & 2 & 10 & 6 & 2 & 7 & 11 \\
\hline D2 & 11 & 10 & 1 & 11 & 1 & 1 & 12 & 5 & 10 & 1 & 12 \\
\hline D3 & 9 & 12 & 2 & 3 & 9 & 3 & 11 & 2 & 1 & 12 & \\
\hline
\end{tabular}

development administration causes the deviation of its structure from the perfect scenario on the given criterion and the decrease of the efficiency of such development. Together with that, it may mean a significant influence on the system of external factors that cannot be handled with its self-regulation mechanism (such as the crisis of 1998).
The results presented in Table 13 show that in the years 2006, 2009, 2011 and 2012 of period 2 the correlation indicators are negative. It means that there was some decrease in the efficiency of socio-economic development that took place in these years. The challenges were faced in the years 2006 and 2009, and 2011-2012 were the years of recovery of the long-lasting 
Table 13. Spearman's and Kendall's correlation coefficients for period 1 (1994-2003)

\begin{tabular}{|c|c|c|c|}
\hline \multirow{2}{*}{ Period } & \multicolumn{3}{|c|}{ Correlation coefficients } \\
\cline { 2 - 4 } & Spearman $\left(\mathrm{K}_{\text {огкл }}\right)$ & Kendall $\left(\mathrm{K}_{\text {инверс }}\right)$ & $\begin{array}{c}\text { Proximity of the actual } \\
\text { structure to the reference }\end{array}$ \\
\hline 1994 & 0.28 & 0.24 & 0.40 \\
\hline 1995 & 0.36 & 0.24 & 0.42 \\
\hline 1996 & 0.50 & 0.33 & 0.50 \\
\hline 1997 & -0.13 & -0.06 & 0.20 \\
\hline 1998 & -0.57 & -0.46 & 0.06 \\
\hline 1999 & 0.08 & 0.06 & 0.29 \\
\hline 2000 & 0.51 & 0.30 & 0.49 \\
\hline 2001 & -0.42 & -0.27 & 0.11 \\
\hline 2002 & 0.34 & 0.24 & 0.41 \\
\hline 2003 & -0.29 & -0.24 & 0.13 \\
\hline
\end{tabular}

Table 14. Spearman's and Kendall's correlation coefficients for period 2 (2004-2013)

\begin{tabular}{|c|c|c|c|}
\hline \multirow{2}{*}{ Period } & \multicolumn{3}{|c|}{ Correlation coefficients } \\
\cline { 2 - 4 } & Spearman $\left(\mathrm{K}_{\text {откл }}\right)$ & Kendall $\left(\mathrm{K}_{\text {инверс }}\right)$ & $\begin{array}{c}\text { Proximity of the actual } \\
\text { structure to the reference }\end{array}$ \\
\hline 2004 & 0.62 & 0.46 & 0.59 \\
\hline 2005 & 0.08 & 0.06 & 0.29 \\
\hline 2006 & -0.33 & -0.21 & 0.13 \\
\hline 2007 & 0.28 & 0.15 & 0.37 \\
\hline 2008 & 0.01 & 0.03 & 0.26 \\
\hline 2009 & -0.75 & -0.58 & 0.03 \\
\hline 2010 & 0.88 & 0.70 & 0.80 \\
\hline 2011 & -0.14 & -0.12 & 0.19 \\
\hline 2012 & -0.43 & -0.36 & 0.09 \\
\hline 2013 & 0.06 & 0.06 & 0.28 \\
\hline
\end{tabular}

financial crisis. After let us calculate the indicator of the ultimate assessment of the proximity of the actual indicator's movement system to the criterion (reference) one on the basis of the two rank correlation coefficients for each time period, using Formula 6.

On the basis of the obtained data, let us build a geometrical model of the actual use of the socio-economic development potential of the country in periods 1 and 2 (Fig. 6). In Fig. 6, we see that the socio-economic development potential of Russia is not used completely. The area around mark " 1 ", marked with red, shows the situation when the socio-economic development potential of Russia is used completely. The area limited with the polygon lines within the same time interval reflects the real value of the socioeconomic development efficiency. From the results of both periods it is possible to conclude that the socio-economic development potential 
of Russia was used as much as possible in the years 2004 and 2010, and its use was minimal in the years 1998 and 2009. We can also conclude that the potential was more efficiently used in period 2 in comparison with period 1 . The value of the socio-economic development efficiency of Russia is calculated with Formula 7. We assume that $\mathrm{R}^{\mathrm{k}}=1$. The results are presented in Tables 14 and 15.

The better the socio-economic development processes of the country are coordinated, the larger $\mathrm{L}$ value is (maximum $\mathrm{L}=1$, minimum $\mathrm{L}=0$ ). The obtained data show that the average coordination value of the processes happening in Russia in periods 1 and 2 is only $40 \%$. For this reason, there is still a great potential for growth. Therefore, the quantitative base of indicators for the assessment of the socio-economic development efficiency of Russia is formed. On the basis of the obtained data let us perform the qualitative assessment of the socio-economic development efficiency to draw a conclusion on the strong and weak sides of such development.

The input for such assessment is the acceleration of indicator's movement for each block of the socio-economic development
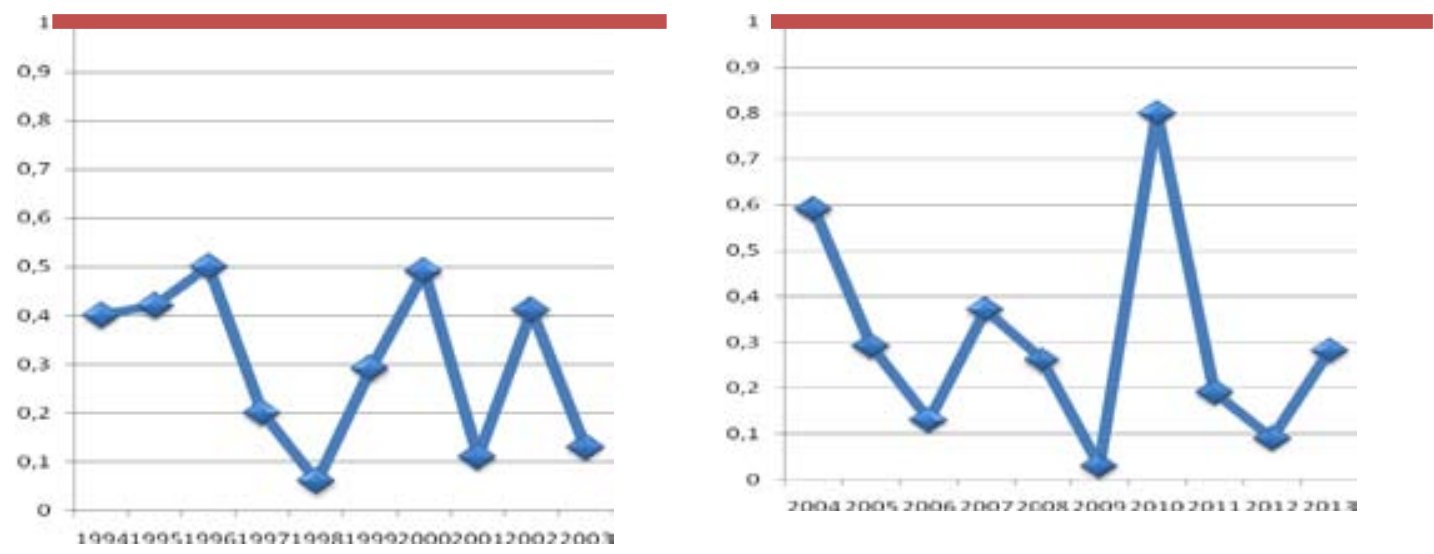

Fig. 6. Model of the actual use of socio-economic development potential in periods 1 and 2

Table 15. Socio-economic development level of Russia in period 1

\begin{tabular}{|c|c|}
\hline \multirow{2}{*}{ Period } & Coordination indicator \\
\hline 1994 & 0.41 \\
\hline 1995 & 0.41 \\
\hline 1996 & 0.42 \\
\hline 1997 & 0.40 \\
\hline 1998 & 0.39 \\
\hline 1999 & 0.41 \\
\hline 2000 & 0.42 \\
\hline 2001 & 0.40 \\
\hline 2002 & 0.41 \\
\hline 2003 & 0.40 \\
\hline
\end{tabular}


processes. One should also consider that the indicators of each block have undergone the ranking procedure, and here we shall use the weighting factors for the acceleration values of each indicator. The weight of each acceleration indicator is determined, on one hand, by its place in the block, and on the other hand, depends on the number of indicators within the block. For this reason, we use the exponential dependence on the number opposite to the sequential number of the indicator in the block. This indicator is calculated with provision for the weighting factors presented in Table 7. For this purpose, the indicators' rank shall be presented within the framework of a certain block for the two periods (Tables 14 and 15).

Let us calculate the mean values of the indicators' acceleration for block A in periods 1 and 2 and present the results in Tables 16 and 17.

Table 16. Socio-economic development level of Russia in period 2

\begin{tabular}{|c|c|}
\hline Period & Coordination indicator \\
\hline 2004 & 0.43 \\
\hline 2005 & 0.41 \\
\hline 2006 & 0.40 \\
\hline 2007 & 0.41 \\
\hline 2008 & 0.41 \\
\hline 2009 & 0.39 \\
\hline 2010 & 0.44 \\
\hline 2011 & 0.40 \\
\hline 2012 & 0.40 \\
\hline 2013 & 0.41 \\
\hline
\end{tabular}

Table 17. Ranking of the acceleration indicators of period 1 (1994-2003) within each process block

\begin{tabular}{|c|c|c|c|c|c|c|c|c|c|c|c|}
\hline \multirow{2}{*}{ No. } & \multicolumn{10}{|c|}{ Actual movement of indicatros } & \multirow{2}{*}{ Reference } \\
\cline { 2 - 13 } & 1994 & 1995 & 1996 & 1997 & 1998 & 1999 & 2000 & 2001 & 2002 & 2003 & 1 \\
\hline A1 & 2 & 3 & 2 & 3 & 1 & 1 & 3 & 2 & 3 & 3 & 2 \\
\hline A2 & 3 & 2 & 1 & 2 & 3 & 3 & 2 & 1 & 1 & 2 & 3 \\
\hline A3 & 1 & 1 & 3 & 1 & 2 & 2 & 1 & 3 & 2 & 1 & 1 \\
\hline B1 & 2 & 1 & 3 & 2 & 3 & 3 & 2 & 1 & 3 & 2 & 2 \\
\hline B2 & 3 & 3 & 1 & 3 & 1 & 1 & 3 & 2 & 2 & 1 & 3 \\
\hline B3 & 1 & 2 & 2 & 1 & 2 & 2 & 1 & 3 & 1 & 3 & 1 \\
\hline C1 & 1 & 1 & 3 & 3 & 2 & 1 & 3 & 2 & 3 & 1 & 2 \\
\hline C2 & 2 & 2 & 1 & 2 & 3 & 2 & 2 & 1 & 1 & 2 & 3 \\
\hline C3 & 3 & 3 & 2 & 1 & 1 & 3 & 1 & 3 & 2 & 3 & 1 \\
\hline D1 & 3 & 1 & 3 & 3 & 1 & 1 & 3 & 2 & 3 & 1 & 2 \\
\hline D2 & 1 & 3 & 2 & 1 & 3 & 3 & 2 & 3 & 1 & 2 & 3 \\
\hline D3 & 2 & 2 & 1 & 2 & 2 & 2 & 1 & 1 & 2 & 3 & \\
\hline
\end{tabular}


Let us calculate the mean values of the indicators' acceleration for block B in periods 1 and 2 and present the results in Tables 17 and 18 .

Let us calculate the mean values of the indicators' acceleration for block $\mathrm{C}$ in periods 1 and 2 and present the results in Tables 19 and 20.
The mean values of the indicators' acceleration for block $\mathrm{D}$ in periods 1 and 2 are presented in Tables 21 and 22.

After that on the basis of the calculation of the mean indicator's acceleration values for each of the four processes in both periods we get the

Table 18. Ranking of the acceleration indicators of period 2 (2004-2013) within each process block

\begin{tabular}{|c|c|c|c|c|c|c|c|c|c|c|c|}
\hline \multirow{2}{*}{ No. } & \multicolumn{10}{|c|}{ Actual movement of indicators } & \multirow{2}{*}{ Reference } \\
\cline { 2 - 12 } & 2004 & 2005 & 2006 & 2007 & 2008 & 2009 & 2010 & 2011 & 2012 & 2013 & 1 \\
\hline A1 & 2 & 3 & 1 & 2 & 2 & 2 & 3 & 2 & 1 & 2 & 2 \\
\hline A2 & 3 & 2 & 3 & 1 & 3 & 1 & 2 & 1 & 3 & 1 & 3 \\
\hline A3 & 1 & 1 & 2 & 3 & 1 & 3 & 1 & 3 & 2 & 3 & 1 \\
\hline B1 & 2 & 2 & 2 & 2 & 1 & 1 & 1 & 3 & 1 & 1 & 2 \\
\hline B2 & 3 & 1 & 3 & 1 & 3 & 3 & 2 & 2 & 2 & 3 & 3 \\
\hline B3 & 1 & 3 & 1 & 3 & 2 & 2 & 3 & 1 & 3 & 2 & 1 \\
\hline C1 & 2 & 1 & 3 & 3 & 1 & 3 & 3 & 1 & 3 & 1 & 2 \\
\hline C2 & 3 & 2 & 1 & 2 & 3 & 2 & 1 & 3 & 2 & 2 & 3 \\
\hline C3 & 1 & 3 & 2 & 1 & 2 & 1 & 2 & 2 & 1 & 3 & 1 \\
\hline D1 & 2 & 1 & 3 & 3 & 3 & 2 & 1 & 3 & 2 & 2 & 2 \\
\hline D2 & 3 & 2 & 1 & 2 & 1 & 1 & 3 & 2 & 3 & 1 & 3 \\
\hline D3 & 1 & 3 & 2 & 1 & 2 & 3 & 2 & 1 & 1 & 3 & 2 \\
\hline
\end{tabular}

Table 19. Mean value of the efficiency indicators for block A in period 1

\begin{tabular}{|c|c|c|c|c|c|c|c|c|c|c|c|}
\hline \multirow{2}{*}{ Indicator } & Weighting & \multicolumn{8}{|c|}{ Mean acceleration value } \\
\cline { 3 - 12 } & factor & 1994 & 1995 & 1996 & 1997 & 1998 & 1999 & 2000 & 2001 & 2002 & 2003 \\
\hline A1 & 0.472 & 0.944 & 1.416 & 0.944 & 1.416 & 0.472 & 0.472 & 1.416 & 0.944 & 1.416 & 1,416 \\
\hline A2 & 0.286 & 0.858 & 0.572 & 0.286 & 0.572 & 0.858 & 0.858 & 0.572 & 0.286 & 0.286 & 0,572 \\
\hline A3 & 0.242 & 0.242 & 0.242 & 0.726 & 0.242 & 0.484 & 0.484 & 0.242 & 0.726 & 0.484 & 0,242 \\
\hline \multicolumn{2}{|c|}{ Mean value } & 0.681 & 0.743 & 0.652 & 0.743 & 0.605 & 0.605 & 0.743 & 0.652 & 0.729 & 0.743 \\
\hline
\end{tabular}

Table 20. Mean value of the efficiency indicators for block A in period 2

\begin{tabular}{|c|c|c|c|c|c|c|c|c|c|c|c|}
\hline \multirow{2}{*}{ Indicator } & \multirow{2}{*}{$\begin{array}{l}\text { Weighting } \\
\text { factor }\end{array}$} & \multicolumn{10}{|c|}{ Mean acceleration value } \\
\hline & & 2004 & 2005 & 2006 & 2007 & 2008 & 2009 & 2010 & 2011 & 2012 & 2013 \\
\hline A1 & 0.472 & 0.944 & 1.416 & 0.472 & 0.944 & 0.944 & 0.944 & 1.416 & 0.944 & 0.472 & 0,944 \\
\hline A2 & 0.286 & 0.858 & 0.572 & 0.858 & 0.286 & 0.858 & 0.286 & 0.572 & 0.286 & 0.858 & 0,286 \\
\hline A3 & 0.242 & 0.242 & 0.242 & 0.484 & 0.726 & 0.242 & 0.726 & 0.242 & 0.726 & 0.484 & 0,726 \\
\hline \multicolumn{2}{|c|}{ Mean value } & 0.681 & 0.743 & 0.605 & 0.652 & 0.681 & 0.652 & 0.743 & 0.652 & 0.605 & 0.652 \\
\hline
\end{tabular}


Table 21. Mean value of the efficiency indicators for Block B in period 1

\begin{tabular}{|c|c|c|c|c|c|c|c|c|c|c|c|}
\hline \multirow{2}{*}{ Indicator } & \multirow{2}{*}{$\begin{array}{c}\text { Weighting } \\
\text { factor }\end{array}$} & \multicolumn{10}{|c|}{ Mean acceleration value } \\
\cline { 3 - 14 } & & 1994 & 1995 & 1996 & 1997 & 1998 & 1999 & 2000 & 2001 & 2002 & 2003 \\
\hline B1 & 0.472 & 0.944 & 0.472 & 1.416 & 0.944 & 1.416 & 1.416 & 0.944 & 0.472 & 1.416 & 0.944 \\
\hline B2 & 0.286 & 0.858 & 0.858 & 0.286 & 0.858 & 0.286 & 0.286 & 0.858 & 0.572 & 0.572 & 0.286 \\
\hline B3 & 0.242 & 0.242 & 0.484 & 0.484 & 0.242 & 0.484 & 0.484 & 0.242 & 0.726 & 0.242 & 0.726 \\
\hline \multicolumn{2}{|c|}{ Mean value } & 0.681 & 0.605 & 0.729 & 0.681 & 0.729 & 0.729 & 0.681 & 0.590 & 0.743 & 0.652 \\
\hline
\end{tabular}

Table 22. Mean value of the efficiency indicators for Block B in period 2

\begin{tabular}{|c|c|c|c|c|c|c|c|c|c|c|c|}
\hline \multirow{2}{*}{ Indicator } & \multirow{2}{*}{$\begin{array}{c}\text { Weighting } \\
\text { factor }\end{array}$} & \multicolumn{10}{|c|}{ Mean acceleration value } \\
\cline { 3 - 14 } & 2004 & 2005 & 2006 & 2007 & 2008 & 2009 & 2010 & 2011 & 2012 & 2013 \\
\hline B1 & 0.472 & 0.944 & 0.944 & 0.944 & 0.944 & 0.472 & 0.472 & 0.472 & 1.416 & 0.472 & 0.472 \\
\hline B2 & 0.286 & 0.858 & 0.286 & 0.858 & 0.286 & 0.858 & 0.858 & 0.572 & 0.572 & 0.572 & 0.858 \\
\hline B3 & 0.242 & 0.242 & 0.726 & 0.242 & 0.726 & 0.484 & 0.484 & 0.726 & 0.242 & 0.726 & 0.484 \\
\hline \multicolumn{2}{|c}{ Mean value } & 0.681 & 0.652 & 0.681 & 0.652 & 0.605 & 0.605 & 0.590 & 0.743 & 0.590 & 0.605 \\
\hline
\end{tabular}

Table 23. Mean value of the efficiency indices for Block $\mathrm{C}$ in period 1

\begin{tabular}{|c|c|c|c|c|c|c|c|c|c|c|c|}
\hline \multirow{2}{*}{ Indicator } & \multirow{2}{*}{$\begin{array}{c}\text { Weighting } \\
\text { factor }\end{array}$} & \multicolumn{10}{|c|}{ Mean acceleration value } \\
\cline { 3 - 12 } & & 1994 & 1995 & 1996 & 1997 & 1998 & 1999 & 2000 & 2001 & 2002 & 2003 \\
\hline $\mathrm{C} 1$ & 0.472 & 0.472 & 0.472 & 1.416 & 1.416 & 0.944 & 0.472 & 1.416 & 0.944 & 1.416 & 0.472 \\
\hline $\mathrm{C} 2$ & 0.286 & 0.572 & 0.572 & 0.286 & 0.572 & 0.858 & 0.572 & 0.572 & 0.286 & 0.286 & 0.572 \\
\hline $\mathrm{C} 3$ & 0.242 & 0.726 & 0.726 & 0.484 & 0.242 & 0.242 & 0.726 & 0.242 & 0.726 & 0.484 & 0.726 \\
\hline \multicolumn{2}{|c|}{ Mean value } & 0.590 & 0.590 & 0.729 & 0.743 & 0.681 & 0.590 & 0.743 & 0.652 & 0.729 & 0.590 \\
\hline
\end{tabular}

Table 24. Mean value of the efficiency indicators for Block $\mathrm{C}$ in period 2

\begin{tabular}{|c|c|c|c|c|c|c|c|c|c|c|c|}
\hline \multirow{2}{*}{ Indicator } & Weighting & \multicolumn{10}{|c|}{ Mean acceleration value } \\
& factor & 2004 & 2005 & 2006 & 2007 & 2008 & 2009 & 2010 & 2011 & 2012 & 2013 \\
\hline $\mathrm{C} 1$ & 0.472 & 0.944 & 0.472 & 1.416 & 1.416 & 0.472 & 1.416 & 1.416 & 0.472 & 1.416 & 0.472 \\
\hline $\mathrm{C} 2$ & 0.286 & 0.858 & 0.572 & 0.286 & 0.572 & 0.858 & 0.572 & 0.286 & 0.858 & 0.572 & 0.572 \\
\hline $\mathrm{C} 3$ & 0.242 & 0.242 & 0.726 & 0.484 & 0.242 & 0.484 & 0.242 & 0.484 & 0.484 & 0.242 & 0.726 \\
\hline \multicolumn{2}{|c|}{ Mean value } & 0.681 & 0.590 & 0.729 & 0.743 & 0.605 & 0.743 & 0.729 & 0.605 & 0.743 & 0.590 \\
\hline
\end{tabular}

matrix for the determination of the weak (the least efficient) and the strong (the most efficient) socio-economic development indicators of a country (Tables 23 and 24).

The changes of values shown in Tables 23 and 24 with provision for the criterion attribute can be used to trace the transformation process of the socio-economic development system and to make conclusions on the reasons that cause such transformation.

To do the qualitative assessment of the transformation process, let us calculate the 
Table 25. Mean value of the efficiency indicators for Block D in period 1

\begin{tabular}{|c|c|c|c|c|c|c|c|c|c|c|c|}
\hline \multirow{2}{*}{ Indicator } & \multirow{2}{*}{$\begin{array}{c}\text { Weighting } \\
\text { factor }\end{array}$} & \multicolumn{8}{|c|}{ Mean acceleration value } \\
\cline { 3 - 12 } & & 1994 & 1995 & 1996 & 1997 & 1998 & 1999 & 2000 & 2001 & 2002 & 2003 \\
\hline D1 & 0.472 & 1.416 & 0.472 & 1.416 & 1.416 & 0.472 & 0.472 & 1.416 & 0.944 & 1.416 & 0,472 \\
\hline D2 & 0.286 & 0.286 & 0.858 & 0.572 & 0.286 & 0.858 & 0.858 & 0.572 & 0.858 & 0.286 & 0,572 \\
\hline D3 & 0.242 & 0.484 & 0.484 & 0.242 & 0.484 & 0.484 & 0.484 & 0.242 & 0.242 & 0.484 & 0,726 \\
\hline \multicolumn{2}{|c|}{ Mean value } & 0.729 & 0.605 & 0.743 & 0.729 & 0.605 & 0.605 & 0.743 & 0.681 & 0.729 & 0.590 \\
\hline
\end{tabular}

Table 26. Mean value of the efficiency indicators for Block D in period 2

\begin{tabular}{|c|c|c|c|c|c|c|c|c|c|c|c|}
\hline \multirow{2}{*}{ Indicator } & \multirow{2}{*}{$\begin{array}{c}\text { Weighting } \\
\text { factor }\end{array}$} & \multicolumn{10}{|c|}{ Mean acceleration value } \\
\cline { 3 - 13 } & 2004 & 2005 & 2006 & 2007 & 2008 & 2009 & 2010 & 2011 & 2012 & 2013 \\
\hline D1 & 0.472 & 0.944 & 0.472 & 1.416 & 1.416 & 1.416 & 0.944 & 0.472 & 1.416 & 0.944 & 0,944 \\
\hline D2 & 0.286 & 0.858 & 0.572 & 0.286 & 0.572 & 0.286 & 0.286 & 0.858 & 0.572 & 0.858 & 0,286 \\
\hline D3 & 0.242 & 0.242 & 0.726 & 0.484 & 0.242 & 0.484 & 0.726 & 0.484 & 0.242 & 0.242 & 0,726 \\
\hline \multicolumn{2}{|c|}{ Mean value } & 0.681 & 0.590 & 0.729 & 0.743 & 0.729 & 0.652 & 0.605 & 0.743 & 0.681 & 0.652 \\
\hline
\end{tabular}

Table 27. Data matrix for the determination of the most and the least efficient trends in socio-economic development in period 1

\begin{tabular}{|l|c|c|c|c|c|c|c|c|c|c|}
\hline \multicolumn{1}{|c|}{$\begin{array}{c}\text { Titles of the socio-economic } \\
\text { development processes }\end{array}$} & \multicolumn{7}{|c|}{ Mean value in the block for the selected period } \\
\cline { 2 - 10 } & 1994 & 1995 & 1996 & 1997 & 1998 & 1999 & 2000 & 2001 & 2002 & 2003 \\
\hline $\begin{array}{l}\text { Main socio-economic } \\
\text { development processes }\end{array}$ & 0.681 & 0.743 & 0.652 & 0.743 & 0.605 & 0.605 & 0.743 & 0.652 & 0.729 & 0.743 \\
\hline $\begin{array}{l}\text { Auxiliary socio-economic } \\
\text { development processes }\end{array}$ & 0.681 & 0.605 & 0.729 & 0.681 & 0.729 & 0.729 & 0.681 & 0.590 & 0.743 & 0.652 \\
\hline $\begin{array}{l}\text { Indirect socio-economic } \\
\text { development processes }\end{array}$ & 0.590 & 0.590 & 0.729 & 0.743 & 0.681 & 0.590 & 0.743 & 0.652 & 0.729 & 0.590 \\
\hline $\begin{array}{l}\text { The processes impeding the } \\
\text { socio-economic development }\end{array}$ & 0.729 & 0.605 & 0.743 & 0.729 & 0.605 & 0.605 & 0.743 & 0.681 & 0.729 & 0.590 \\
\hline
\end{tabular}

Table 28. Data matrix for the determination of the most and the least efficient trends in socio-economic development in period 2

\begin{tabular}{|l|c|c|c|c|c|c|c|c|c|c|}
\hline \multicolumn{1}{|c|}{$\begin{array}{c}\text { Titles of the socio-economic } \\
\text { development processes }\end{array}$} & \multicolumn{6}{|c|}{ Mean value in the block for the selected period } \\
\cline { 2 - 11 } & 2004 & 2005 & 2006 & 2007 & 2008 & 2009 & 2010 & 2011 & 2012 & 2013 \\
\hline $\begin{array}{l}\text { Main socio-economic } \\
\text { development processes }\end{array}$ & 0.681 & 0.743 & 0.605 & 0.652 & 0.681 & 0.652 & 0.743 & 0.652 & 0.605 & 0.652 \\
\hline $\begin{array}{l}\text { Auxiliary socio-economic } \\
\text { development processes }\end{array}$ & 0.681 & 0.652 & 0.681 & 0.652 & 0.605 & 0.605 & 0.590 & 0.743 & 0.590 & 0.605 \\
\hline $\begin{array}{l}\text { Indirect socio-economic } \\
\text { development processes }\end{array}$ & 0.681 & 0.590 & 0.729 & 0.743 & 0.605 & 0.743 & 0.729 & 0.605 & 0.743 & 0.590 \\
\hline $\begin{array}{l}\text { The processes impeding the } \\
\text { socio-economic development }\end{array}$ & 0.681 & 0.590 & 0.729 & 0.743 & 0.729 & 0.652 & 0.605 & 0.743 & 0.681 & 0.652 \\
\hline
\end{tabular}


synchrony level of socio-economic development. The synchrony level (SY) is appropriate to be determined with regard to the indicators of the main socio-economic development processes (group A processes) as they are the ones determining a country's development tendency. This indicator reflects the synchrony level of other socio-economic development processes in relation to the main ones.

The indicators varies from -1 to +1 ; the highest value means the absolute synchrony of processes while the lowest stands for the complete asynchrony of the processes. First with the help of SPSS Statistics 17.0 we shall calculate the Pearson coefficients of correlation between the development rate of the main and auxiliary processes, between the development rate of the main and indirect processes and finally the between development the rate of the main processes and the processes impeding the socioeconomic development.
The synchrony level is determined with Formula 3.9.

Table 25 shows that the synchrony level in period 1 is positive, but this value $(0,03)$ is very close to 0 ; therefore, it is hard to speak of any synchrony of the socio-economic development of Russia in period 1 (1994-2003).

Nevertheless, the value is still positive, therefore, the quality of the socio-economic development of Russia can be assessed as synchronous.

Table 26 shows that the synchrony level in period 2 is negative. It means that from the year 2004 till the year 2013 the socio-economic development of Russia was not efficient enough and some asynchrony of the development took place. Thus, on the basis of the results of the socio-economic development of Russia for the two periods obtained with the method adjusted by the authors, it was found that the efficiency of the socio-economic development of Russia decreases

Table 29. Synchrony level of socio-economic development in period 1

\begin{tabular}{|c|c|c|}
\hline Indicators & $\begin{array}{c}\text { Correlation } \\
\text { coefficient (Pearson) }\end{array}$ & Synchrony level \\
\hline $\begin{array}{l}\text { Development rate of the main and auxiliary socio-economic } \\
\text { development processes }\end{array}$ & -0.348 & \multirow{3}{*}{$\mathrm{SY}=0.03$} \\
\hline $\begin{array}{l}\text { Development rate of the main and indirect socio-economic } \\
\text { development processes }\end{array}$ & 0.181 & \\
\hline $\begin{array}{l}\text { Development rate of the main processes and the processes impeding } \\
\text { the socio-economic development }\end{array}$ & 0.258 & \\
\hline
\end{tabular}

Table 30. Synchrony level of socio-economic development in period 2

\begin{tabular}{|l|c|c|}
\hline \multicolumn{1}{|c|}{ Indicators } & $\begin{array}{c}\text { Correlation } \\
\text { coefficient (Pearson) }\end{array}$ & Synchrony level \\
\hline $\begin{array}{l}\text { Development rate of the main and auxiliary socio-economic } \\
\text { development processes }\end{array}$ & -0.135 & SY $=-0.385$ \\
\hline $\begin{array}{l}\text { Development rate of the main and indirect socio-economic } \\
\text { development processes }\end{array}$ & -0.35 & -0.67 \\
\hline $\begin{array}{l}\text { Development rate of the main processes and the processes impeding } \\
\text { the socio-economic development }\end{array}$ & -25 \\
\hline
\end{tabular}


even though some official statistic indicators are positive and seem to be indicating some stable growth. Now let us study the transformation of the socio-economic development depending on the process development type. Let us designate them as successful, depressive and retarded development types (Table 27).

Let us study the typology of actual socioeconomic development of Russia in period 1 (Table 28).

In Table 28, we can see that the perfect socio-economic development was observed in the year 2003. That year showed some stable growth of the socio-economic indicators of Russia.

Let us study the typology of actual socioeconomic development of Russia in period 2 (Table 29).

In Table 29, we can see that the perfect socio-economic development was observed in the years 2004 and 2005. Nevertheless, in the year 2004 there was no acceleration growth; all the indicators were equal.

Let us make Table 30 for the two periods indicating the types of socio-economic development of each year of the period.

The results presented in Table 30 draw the conclusion that during the crisis and postcrisis periods the whole system of the socioeconomic development of Russia consisted of non-systematic and separate processes. There were more of such non-systematic years in period 1 , i.e. during the transitional economy period. In period 2 the systematicity and efficiency of the socio-economic development growth is clearer, but the crisis of the years 2008-2009 and the post-crisis period shows that the economy of the country was not yet ready to face such global problems and only by the year 2013 Russia had

Table 31. Typology of socio-economic development of a country

\begin{tabular}{|l|l|l|}
\hline $\begin{array}{l}\text { Typological nomination of efficiency of socio-economic } \\
\text { development }\end{array}$ & \multicolumn{1}{|c|}{ Development type } & \multicolumn{1}{c|}{ Dynamic structure } \\
\hline Successful (perfect) & Stable growth & AB $>$ C $>$ D \\
\hline Successful & Unstable growth & AB $>$ D $>$ C \\
\hline Depressive I & Unstable growth & C $>$ AB $>$ D \\
\hline Depressive II & Unstable decrease & C $>$ D $>$ AB \\
\hline Retarded I & Unstable decrease & D $>$ AB $>$ C \\
\hline Retarded II & Stable decrease & D $>$ C $>$ AB \\
\hline
\end{tabular}

Table 32. Typology of socio-economic development of Russia in period 1

\begin{tabular}{|l|c|c|c|c|c|c|c|c|c|c|}
\hline \multicolumn{1}{|c|}{$\begin{array}{c}\text { Socio-economic development } \\
\text { processes }\end{array}$} & \multicolumn{7}{|c|}{ Acceleration rank } \\
\cline { 2 - 11 } & 1994 & 1995 & 1996 & 1997 & 1998 & 1999 & 2000 & 2001 & 2002 & 2003 \\
\hline $\begin{array}{l}\text { Main socio-economic } \\
\text { development processes }\end{array}$ & 2 & 1 & 4 & 1 & 3 & 2 & 1 & 2 & 2 & 1 \\
\hline $\begin{array}{l}\text { Auxiliary socio-economic } \\
\text { development processes }\end{array}$ & 3 & 2 & 2 & 4 & 1 & 1 & 4 & 4 & 1 & 2 \\
\hline $\begin{array}{l}\text { Indirect socio-economic } \\
\text { development processes }\end{array}$ & 4 & 4 & 3 & 2 & 2 & 4 & 2 & 3 & 3 & 3 \\
\hline $\begin{array}{l}\text { The processes impeding the } \\
\text { socio-economic development }\end{array}$ & 1 & 3 & 1 & 3 & 4 & 3 & 3 & 1 & 4 & 4 \\
\hline
\end{tabular}


Table 33. Typology of socio-economic development of Russia in period 2

\begin{tabular}{|l|c|c|c|c|c|c|c|c|c|c|}
\hline \multicolumn{1}{|c|}{$\begin{array}{c}\text { Socio-economic development } \\
\text { processes }\end{array}$} & \multicolumn{7}{|c|}{ Mean value of the block for the selected period } \\
\cline { 2 - 11 } & 2004 & 2005 & 2006 & 2007 & 2008 & 2009 & 2010 & 2011 & 2012 & 2013 \\
\hline $\begin{array}{l}\text { Main socio-economic } \\
\text { development processes }\end{array}$ & 1 & 1 & 4 & 3 & 2 & 2 & 1 & 3 & 3 & 1 \\
\hline $\begin{array}{l}\text { Auxiliary socio-economic } \\
\text { development processes }\end{array}$ & 2 & 2 & 3 & 4 & 3 & 4 & 4 & 1 & 4 & 2 \\
\hline $\begin{array}{l}\text { Indirect socio-economic } \\
\text { development processes }\end{array}$ & 3 & 3 & 1 & 1 & 4 & 1 & 2 & 4 & 1 & 4 \\
\hline $\begin{array}{l}\text { The processes impeding the } \\
\text { socio-economic development }\end{array}$ & 4 & 4 & 2 & 2 & 1 & 3 & 3 & 2 & 2 & 3 \\
\hline
\end{tabular}

Table 34. Types of socio-economic development of Russia in periods 1 and 2

\begin{tabular}{|c|c|c|c|c|c|c|c|c|c|c|}
\hline Period 1 & 1994 & 1995 & 1996 & 1997 & 1998 & 1999 & 2000 & 2001 & 2002 & 2003 \\
\hline $\begin{array}{l}\text { Typological } \\
\text { nomination of the } \\
\text { socio-economic } \\
\text { development } \\
\text { efficiency }\end{array}$ & 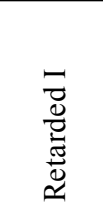 & $\begin{array}{l}\bar{E} \\
\tilde{n} \\
0 \\
0 \\
0 \\
0 \\
\tilde{D}\end{array}$ & ' & ' & ' & ' & ' & 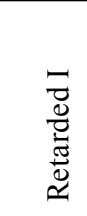 & ' & 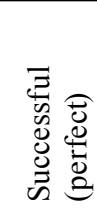 \\
\hline Period 2 & 2004 & 2005 & 2006 & 2007 & 2008 & 2009 & 2010 & 2011 & 2012 & 2013 \\
\hline $\begin{array}{l}\text { Typological } \\
\text { nomination of the } \\
\text { socio-economic } \\
\text { development } \\
\text { efficiency }\end{array}$ & 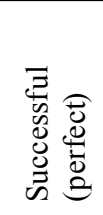 & 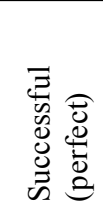 & 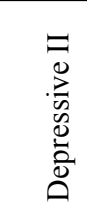 & 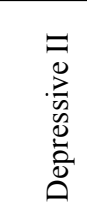 & 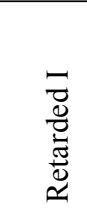 & ' & 1 & ' & 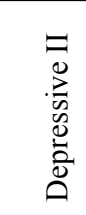 & 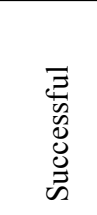 \\
\hline
\end{tabular}

managed to reach a successful development level. Therefore, we can conclude that in period 2 the socio-economic development indicators were better systematized and easier to assess. In the event of successful (perfect) development of the socio-economic indicators (marked in the years 2003-2005) the growth rate of the main and auxiliary processes exceeds that of the indirect processes. In such a case, we may speak of some stable and sustainable socio-economic growth: the life standards are rising, the unemployment rate remains low, industry and social infrastructure continue to develop along with some other attributes of high economic activity.

In the event of successful development of the socio-economic indicators (market in the years 1995 and 2013), the main peculiarity is the advanced growth of the processes impeding socio-economic development in comparison with that of the indirect processes. On the basis of the data of the year 2013, we can imagine two scenarios of the socio-economic development. In one of them the indirect processes growth rate increases and that of the processes impeding development decreases, which is peculiar for the economy diversification mode.

In the other one, the situation worsens, causing the transformation of the socio-economic development into the depressive type. Not to let it happen the country should strive for the perfect model of socio-economic development as it was in the years 2003-2005. 
In the years 2014-2015 it is required to pay some attention to the growth of the following elements of the socio-economic development: to increase the minimum cost of living in the country; to improve the conditions that allow to increase the money income and personal savings of the population; to develop new ways of providing the population with housing under new governmental programmes; to decrease the mortgage rates; to simplify the administrative formalities required for the construction of new residential houses.

To approach the perfect model of the efficient socio-economic development, our country needs to apply the methodology developed with the statistic information system software to complete the automatisation of the socio-economic development efficiency assessment in order to increase the accuracy of such development analysis and to provide timely detection of any discrepancies of the socio-economic processes; on the basis of continuous monitoring of the socioeconomic potential of the country's development, to design the socio-economic development programmes to treat the indicators systematically, not individually; to continue further research in the field of increasing the efficiency of the socioeconomic development of Russia with the help of the current method, using a more detailed and expanded number of indicators, considering every administrative entity, city, economic zone or industrial branch of our country.

Therefore, the obtained results helped to form the adjusted scenarios of development of the socio-economic indicators of the country, similar to those of the life cycles of economic processes: formation, development, recession, and depression.

The development stages depend on the socio-economic development indicators development rate described in the efficiency assessment methodology. After the assessment of the socio-economic development efficiency with the help of the suggested methodology, we should work to design a perfect model of the socio-economic development administration model. The perfect model of the efficient socioeconomic development is a system where all the indicators are coordinated, synchronized and efficient.

The suggested adaptive methodology can be used at various levels of administration; it is relatively easy to use and has the capacity to research various qualitative and quantitative indicators of the socio-economic development of the country. The use of the method and the development of strategic solutions on its base may help to achieve the socio-economic development system of Russia that would be maximally close to the perfect model.

\footnotetext{
Figure based on the analysis carried out by the author.

Figure made by the author on the basis of Rosstat data published on http://www.gks.ru www.gks.ru

In the present research the version SPSS 17.0 was used
}

\section{References}

Bandurin, V.V. Globalizatsiia mirovoi ekonomiki i Rossiia [World economy globalization and Russia]. Moscow, Bukvitsa, 1999. P. 21.

Biiakov, O.A. Teoriia ekonomicheskogo prostranstva: metodologicheskii i regional'nyi aspekty [Economic space theory: methodological and regional aspects]. Tomsk University press, 2004.

Ekonomicheskaia kibernetika [Economic cybernetics]. Ed. by I.M. Syroezhin. Vol. IV. Leningrad Institute of Finance and Economics, 1976. 
Fedorenko, N.P. Sistemnyi podkhod k izucheniiu ekonomicheskikh iavlenii [Systematic approach to the economic phenomena studies]. Matematika i kibernetika $v$ ekonomike [Mathematics and cybernetics in economics]. Moscow, Ekonomika, 1975. P. 517.

Galbraith, J. Krizis globalizatsii [The crisis of globalization]. http://www.ptpu.ru/issues/6_99/ 5_6_99.htm.

Illarionov, A. (1996). Modeli ekonomicheskogo razvitiia i Rossiia [Economic development models and Russia]. Questions of economics, 7, 5.

Korovkin, A.G. (2013). Dinamika zaniatosti i rynka truda v RF v perspektive do $2030 \mathrm{~g}$. [Dynamics of employment rate and labour market in the RF in the prospective until 2030]. Problemy prognozirovaniia, 4,79 .

Lopatnikov, L.I. Ekonomiko-matematicheskii slovar' [Dictionary of economics and mathematics]. Moscow, ABG, 1996. P. 489.

Lomova, E.A. (2010). Osobennosti sberezhenii dokhodov domashnikh khoziaistv kak osnovy finansirovaniia investitsii $\mathrm{v}$ Rossii [Peculiarities of the household income savings as a basis for financing investments in Russia]. Chelyabinsk state university newsletter, 26, 27-32.

Pogostinskaia, N.N., Pogostinskii, R.L. \& Zhambekova R.L. Ekonomicheskaia diagnostika: teoriia i metody [Economic diagnostics: theory and methods]. Nalchik, El'brus, 2000. 319 p.

Syroezhin, I.M. Sovershenstvovanie sistemy pokazatelei effektivnosti i kachestva [Efficiency and quality indices system improvement]. Moscow, Ekonomika, 1980. 192 p.

Tiukhtin, V.S. Otrazhenie, sistemy, kibernetika [Reflection, systems, cybernetics]. Moscow, Nauka, 1972. P. 11.

Tsygichko, V.N. Rukovoditeliu - o priniatii reshenii [To the manager: decision-making issues]. Moscow, Finansy i statistika, 1991. P.9.

Uziakov, M.N. \& Shirov, A.A. (2012). Makroekonomicheskaia dinamika rossiiskoi ekonomiki $\mathrm{v}$ dolgosrochnoi perspektive [Macroeconomic dynamics of Russian economy in the long-term prospective]. Problemy prognozirovaniia, 6, 15 .

Wishlade, F. Sistemy vydeleniia regionovv Evrope: vozmozhnye uroki dlia Rossii [Area designation systems in Europe: possible lessons for Russia]. http://ieie.nsc.rul tacis\r_yuill.htm 


\section{Методика формирования системы показателей \\ для оценки эффективности \\ социально-экономического развития}

С.К. Демченко, Т.А. Мельникова

Сибирский федеральный университет

Россия, 660041, Красноярск, пр. Свободный, 79

На социильно-экономическое развитие любой страны влияют факторы, вызванные глобализацией. Одной из важнейших проблем взаимозависимого мирового сообщества является уже не сотрудничество различных сочиально-экономических систем, а взаимодействие разноуровневых хозяйственных структур, характеризующихся не только степенью развития, но степенью вовлеченности в мировое разделение труда и мировое хозяйство, причем, как точно отмечает В. Бандурин: «..государственные границь постепенно утрачивают свое значение, становятся все более прозрачными, дают все больше возможностей для свободы перемещчения всех видов ресурсов» (Bandurin, 1999).

Ключевые слова: общественное производство, сочиильно-экономическое развитие, интеграционные прочессы, трансформация.

Научная специальность: 08.00.00 - экономические науки. 